\title{
ЗНАК, МЕТАФОРА, СИМВОЛ - МЕТОДОЛОГИЯ СУБЪЕКТНОСТИ
}

\section{Д.Э. ВОЛКОВА, А.Б. ОРЛОВ, Н.А. ОРЛОВА}
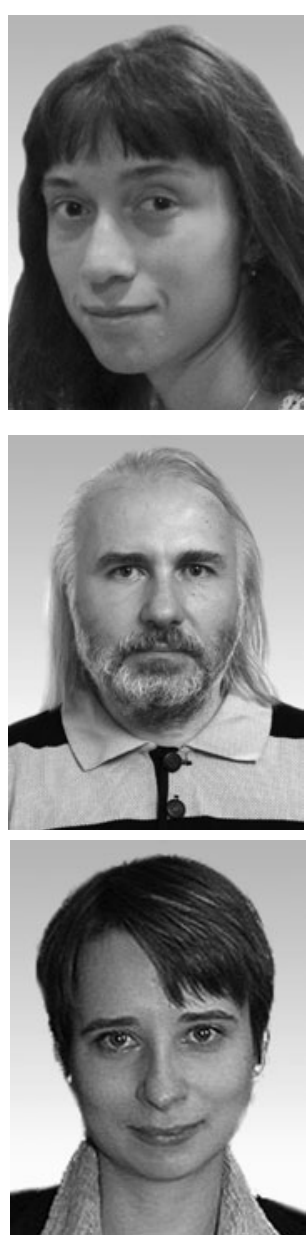

Волкова Дарья Эммануиловна - аспирантка факультета психологии ГУ-ВШЭ кафедры психологии личности.

Область научных интересов - самопознание, образные средства самопонимания, теория и методология психотерапии.

Контакты: rees@rambler.ru

Орлов Александр Борисович - профессор кафедры психологии личности факультета психологии ГУ-ВШЭ, доктор психологических наук, руководитель магистерской программы «Исследование, консультирование и психотерапия личности».

Контакты: aorlov@hse.ru

Орлова Наталия Александровна - кандидат философских наук, старший преподаватель кафедры культурологии факультета гуманитарных наук МФТИ (НИУ), старший научный сотрудник Института психолого-педагогических проблем детства РАО.

E-mail: n.orlova@newmail.ru 


\begin{abstract}
Резюме
В статье с опорой на философскую и психологическую зарубежную и отечественную традиции рассматриваются три формь опосредования: знаковая, метафорическая и символическая; анализируется их связь со становлением субъектных смысловых структур человека, а также их роль и место в психотерапевтическом процессе. Выделяются, дифференцируются и описываются знаковые, метафорические и символические способы выражения внутренних содержаний клиента в процессе психотерапии, показывается связь способов опосредования с трехаспектной структурой субъектности, выделяемой в триалогическом подходе.
\end{abstract}

Ключевые слова: субъектность, знак, означение, метафора, метафоризация, символ, символизация, психотерапия, триалогический подход.

\section{Введение}

В сфере современной отечественной философско-социологической мысли человек рассматривается как субъект деятельности, производящий два класса объектов - вещи и знаки (Момджян, 1997). Различение объектов этих двух классов позволяет на уровне методологии описывать, классифицировать и исследовать все области человеческой жизнедеятельности. При этом содержание предельно широкого по объему понятия «знак» включает в себя только один признак - способность объекта передавать информацию, независимо от качества, типа и способа передачи информации. В силу этого все физические объекты (в широком смысле слова) можно континуально расположить между полюсами пре- дельной «вещности» (объект рассматривается только как физический) и предельной «знаковости» (объект рассматривается как информационный, при этом его физической составляющей можно пренебречь).

Логика философско-методологической конкретизации подобной оппозиции базируется на вопросах о бытийном статусе идеального 1 : что представляет собой знаковость? является ли знаковость единственной формой передачи информации?

При еще большей конкретизации эти вопросы оказываются вопросами о статусе сознания и языка как выразительного средства в широком смысле слова.

Начиная с конца XIX в. именно «язык» и «сознание» ${ }^{2}$ становятся ведущими темами философского дискурса разных школ и направлений и

\footnotetext{
${ }^{1}$ В европейской философской традиции утверждение о самостоятельном бытии идеального связывается с платонической традицией (в отечественной философии проблема идеального детально была рассмотрена Э.В. Ильенковым (Ильенков, 2009)).

${ }^{2}$ Способы философствования относительно языка и сознания начиная с Нового времени и до кульминационного бума в конце XIX - начале XXI в. подробно раскрыт В.В. Васильевым в монографии «Трудная проблема сознания» (Васильев, 2009).
} 
одной из важнейших исследовательских территорий в различных научных сферах, таких как лингвистика и семиотика, психология и психотерапия, когнитивная наука и кибернетика, культурология и этнография и т. д.

Представленные ниже три языка или три формы опосредования: знаковая - метафорическая - символическая, на наш взгляд, отражают внутреннюю структуру субъектности, состоящую из трех уровней: на первом уровне субъектности, связанном со знаковым языком, представлены предметные смыслы; данный уровень - это уровень самоопределения человека как некого, обладающего теми или иными качествами социального индивида, подпадающего под разные общепринятые категориальные обозначения: «студент», «домохозяйка», «блондинка», «невротик» и т.д. Посредством данного уровня субъектности, опосредованного знаком, человек «вписывается» в общественную структуру, определяет свой социальный статус и закрепляет за собой определенные паттерны поведения-мышления-чувствования, характерные для представителей определенной категории.

На втором, опосредованном метафорическим языком уровне субъектности представлены личностные смыслы и переживания человека, позволяющие ему ощущать себя как уникальную индивидуальность (в терминологии психологии личности), не сводимую к набору признаков, не умещающуюся ни в какие категориальные рамки, постоянно развивающуюся, многоликую, многоплановую и способную к изменениям, «текучую». Метафора, понимаемая нами предельно широко (что совпадает с понятием тропа в риторике), идеально подходит на роль опосредующего звена, средства выражения и конституирования субъектности. Данный уровень субъектности, как нам представляется, является менее формальным, не столь жестко структурированным, потенциально более располагающим к диалогу (полилогу), нежели предыдущий. Именно на этом уровне существуют экзистенциальные вызовы, решаются экзистенциальные задачи, связанные со свободой и ответственностью, личностным самоопределением, смыслом жизни и т. д.

Находясь на третьем уровне субъектности, опосредованном символом, человек достигает особого рода состояний, которые на качественно новом этапе «снимают» (в гегелевской терминологии) уникальность индивидуальности, утвержденную на предыдущем уровне, и позволяют ему достигать живой связи с иными «реальностями», будь то божественная/нуминозная или бессознательная/архетипическая человеческая реальность. На третьем, символическом уровне опосредования субъектности человек испытывает потребность в трансценденции как социальных, так и научных, психологических рамок самоопределения, в самоопределении в контекстах религиозных, философских или мистических традиций.

Однако прежде чем мы подойдем к рассмотрению уровней субъектности, хотелось бы более детально проанализировать сами средства опосредования, чтобы прояснить используемую нами терминологию. Это немаловажно, поскольку, как уже говорилось выше, «язык» был важной 
темой исследований и в разных научных дисциплинах: философской риторике, семиотике, лингвистике, психологии, искусствознании, эстетике и т. д. В каждой из этих дисциплин сложились свои концептуальные (терминологические) системы. Поскольку для нас различение знака, метафоры и символа является принципиальным методологическим моментом, мы предпримем философско-культурологический экскурс, с помощью которого покажем значимые различия этих трех средств опосредования.

\section{Символическое отношение: историко-философский анализ}

\section{Понятие символической функции у Э. Кассирера и К.Г. Юнга}

В первую очередь следует указать на философские и историко-культурологические работы, появившиеся практически одновременно и выдвинувшие понятия знака и символа на первый план, описывая с их помощью «человеческое как таковое». К ним относятся философские построения Э. Кассирера, поместившего символическую функцию в самое средоточие культуры и видевшего в ней ту демаркационную линию, которая пролегает между человеком (homo symbolicus) и всем остальным животным миром, и К.Г. Юнга, видевшего в символической функции ${ }^{3}$ особую интегративную психическую силу процесса индивидуации, обеспечивающую появление homo totus'a из раздробленных психических фрагментов.

Символ, будучи центральным понятием философии Э. Кассирера ${ }^{4}$, вписан в ряд оппозиций, позволяющих дать ему более точное определение. По сути дела, «символическое» оказывается у Э. Кассирера характерной чертой собственно человеческого существования, выражающейся в способности человека порождать символические формы, в совокупности образующие феномен культуры. Символизация противопоставляется Э. Кассирером, с одной стороны, имитации (копированию, репродукции) (Cassirer, 1979, p. 167), а с другой, интуитивному непосредственному (чувственному или интеллектуальному) схватыванию, благодаря чему символизация оказывается новым способом бытия в мире, позволяющим не только существовать в реальности, но и интерпретировать ее (там же, р. 194-195).

В отличие, например, от феноменологии, ориентированной на интеллектуальное непосредственное схватывание ноуменов (смысловых данностей), и сенсуализма, видящего источник познания в непосредственном чувственном восприятии сенсорных данных (sense data), философия Э. Кассирера базируется на интерпретирующей способности человеческого сознания, позволяющей преодолеть границы детерминированности

\footnotetext{
${ }^{3}$ Эссе «Трансцендентная функция» было написано К.Г. Юнгом в 1916 г.

${ }^{4}$ Основные идеи символизма изложены Э. Кассирером в трехтомнике «Философия символических форм» (Т. 1. «К феноменологии языковой формы» (1923); Т. 2. «Мифическое мышление» (1925); Т. 3 «Феноменология познания» (1929)).
} 
(реальности) и оказаться в сфере свободы (возможности). Наличие такой способности позволяет даже слепоглухонемому ребенку (Э. Кассирер приводит примеры Элен Келлер и Лоры Бриджмен - Кассирер, 1998, с. 479-481) овладеть сферой возможного (там же, с. 507-508), научиться тому, что имена и вещи связаны не однозначными, детерминированными обстановкой связями а интерсубъективны и изменчивы (у одной вещи могут быть разные имена, и одно имя может быть у разных вещей).

Таким образом, начатая И. Кантом $^{6}$ критика разума развернулась у Э. Кассирера в исследовательскую программу по поиску оснований культуры (языка, мифа, искусства, религии, науки), приведшую его к заключению, что в основании различных культурных миров лежит «априорная форма» - символическая функция, «пробуждение» которой в ребенке позволяет ему стать полноценным членом сообщества людей и переводит его из сферы реальности (каузальных связей, эмоциональных и поведенческих реакций) в сферу смысла, из мира физических свойств и связей - в мир «значащих знаков» (Cassirer, 1979, p. 136).

В некотором смысле К.Г. Юнг также исходил из кантианских представлений об априорных условиях синтеза в своем понимании архети- пов и символической функции. Однако предельно широкое по объему понятие символической функции у Э. Кассирера как априорной формы принципиальной означаемости (если говорить в терминах семиотики) у К.Г. Юнга сужено до понимания ее как более специфической априорной формы, интегрирующей сознательные и бессознательные содержания психики и порождающей особые образования - символы. В понимаемой таким образом символической функции именно синтетический момент выходит на первый план, тогда как означение символических образов имеет инструментальный, вспомогательный характер.

К.Г. Юнг указывает, что созданный символической функцией материал (ментальные или пластические образы) могут не интерпретироваться, а только проживаться, меняясь не в результате их означения (т. е. интерпретации, перевода на другой язык, например, вербально-понятийный), а в результате интенсивного проживания. Например, рисунок как результат действия символической функции можно рассматривать не только как означающее (план выражения), которому нужно подыскать подходящее означаемое (план содержания) и тем самым перейти от него к чему-то другому. При подобном подходе образы утрачивают свою значимость после интерпретации (так, «меч», понятый как «половой орган»,

\footnotetext{
${ }^{5}$ По Э. Кассиреру, животные могут воспринимать отдельные знаки в качестве жестко обусловленных наличной обстановкой сигналов (Кассирер, 1998, с. 477).

${ }^{6}$ Следует отметить, что и Э. Кассирер, и К.Г. Юнг во многом своими идеями были обязаны И. Канту: Э. Кассирер был представителем марбургской школы неокантианства, а К.Г. Юнг ссылался на формы чистого разума И. Канта при описании архетипов.
} 
перестает быть интересен в качестве «меча»), вместо того чтобы «разыгрываться» и проживаться, как разыгрывается и проживается образ в игре актера. Такие спонтанно созданные психической активностью человека и проживаемые им состояния К.Г. Юнг называет «живыми символами».

Данный подход поощряет скорее воздержание от интерпретирования и удержание образа в его целостности и самобытности, поскольку зачастую именно интерпретация «убивает» символ, понятый по принципу «это всего лишь». Так, например, согласно К.Г. Юнгу, живой символ Христа, проживаемый католиками в таинстве причастия, в протестантизме был низведен до «воспоминаний о Христе», что привело к тому, что причастие «Богу живому» стало воспоминанием о «Боге жившем»; тем самым была разрушена возможность ритуального синтеза сознательных состояний человека с силами коллективного бессознательного.

Еще одной особенностью символической функции К.Г. Юнга является изменение уровня и качества интеграции сознания и бессознательного при каждой ее актуализации, что проявляется в изменении отноше- ний между интрапсихическими структурами (инстанциями) человека. Поэтому символическая функция оказывается не столько способностью порождать различные «символические миры», сколько способностью «трансмутировать» (если использовать язык алхимии) своего носителя, при этом «символические миры» выполняют функцию проекционного вспомогательного инструмента.

Если символические формы по Э. Кассиреру (язык, миф, наука, искусство и т. д.) следует рассматривать как различные, но все же «рядоположенные» символические языки ${ }^{7}$, то для описания символической функции по К.Г. Юнгу можно использовать метафору вертикали, поскольку в процессе индивидуации каждый раз порождаются качественно разноуровневые, иерархически организованные символические формы, позволяющие человеку продвигаться от состояния психической фрагментированности ко все большей и большей «индивидности». Такое понимание символической функции было зафиксировано К.Г. Юнгом и в ее названии (опять же в духе кантианской традиции) - «трансцендентная», или «трансцендентальная» ${ }^{8}$

\footnotetext{
${ }^{7}$ Логическим завершением этой линии можно рассматривать представления Р. Барта о культуре (идеологии) как о сети коннотаций (соозначений), или кодов. Все коннотации (коды) равноценны и рядоположены (см., напр.: Барт Р. Избранные работы. Семиотика. Поэтика. М.: Прогресс; Универс, 1994; Барт P. S/Z. M.: Ad Marginem, 1994; Барт Р. Мифологии. М.: Изд-во им. Сабашниковых, 1996). Выделение того или иного кода и его превалирование над другими осуществляется за счет дополнительных, внеположенных семиозису властных санкций.

${ }^{8}$ В разных текстах дается разное название, и хотя в философской традиции эти два термина имеют разное значение, в концепции К.Г. Юнга для названия функции корректно подходят оба: функция может быть названа «трансцендентной», поскольку она внеположена другим четырем функциям; она может быть названа и «трансцендентальной», поскольку действует на границе сознания и бессознательного, объединяя их содержания в некоторое новое единство.
} 
Символическая функция, рассматриваемая Э. Кассирером в контексте исследований семиотики и поэтики, может быть названа «семиотической функцией», или «знаковой функцией». Став предметной областью целой науки, семиозис (как процесс порождения и функционирования знаков) был скрупулезно изучен и описан. В целях нашего дальнейшего анализа средств субъектности необходимо хотя бы вкратце коснуться данной понятийной системы, чтобы избежать терминологического разночтения.

\section{Знак: поле интерпретащий}

\section{Знаковое отношение в семиотике}

Обращение к семиотическим дисциплинам позволяет отождествить «символ» Э. Кассирера со «знаком как таковым», или процессом семиозиса. Рассматривая знак как таковой, семиотика взяла в качестве базовой классификацию знаков Ч. Пирса, предложившего в работе «О новом списке категорий» (1867) делить знаки по способу означения на иконические (подобие), индексальные (смежность) и условные, или символы (конвенциональность) (Якобсон, 1983).

Впоследствии Ф. де Соссюр противопоставил символы конвенциональным знакам, подчеркнув в первых иконический элемент (Лотман, 1992). Он иллюстрировал данное положение следующим примером: весы (а не повозка) являются символом правосудия, потому что ико- нически содержат в себе представление о равновесии.

Из этих концепций возникло два авторитетных направления, одно из которых нашло отражение в символической логике и математике, тогда как во втором символ рассматривался как иконический знак, включался (как в поэтике) в классификацию тропов.

Поэтика обычно включается в семиотические науки. Означающее и означаемое при этом синонимически соотносятся соответственно с планом выражения и планом содержания.

Подобным же образом в зависимости от контекста знаки и выражения интерпретируются как денотативные (денотация - «означение», «буквальный смысл») и коннотативные (коннотация - «со-означение», «переносный, добавочный смысл»). Например, изображение быка может указывать как на само животное (уровень денотации), так и на мифологические мотивы плодородия и порождения (уровень коннотации).

\section{Метафорическое отношение в поэтике}

В поэтике коннотированные выражения называют тропами (от греч. tropos - «поворот»), или риторическими фигурами, среди которых ${ }^{9}$ по наибольшей употребимости можно выделить метафору (соотношение двух значений по сходству), метонимию (по смежности) и оксиморон (по контрасту).

Поскольку, на наш взгляд, терминологическое разведение знака,

\footnotetext{
${ }^{9}$ Подробно все типы тропов классифицированы и описаны в работе льежской «группы мю»: Общая риторика. М.: Прогресс, 1986.
} 
метафоры и символа является принципиальным, имеет смысл остановиться на том, как эти понятия соотносятся между собой в поэтике.

Символ чаще всего рассматривался либо как троп, либо как разновидность метафоры.

Взгляд на символ как на троп можно найти у П. Рикера, который в работе «Конфликт интерпретаций» пишет о том, что придает слову «символ» более узкий смысл, чем те авторы, которые, как Э. Кассирер, называют символическим всякое восприятие реальности с помощью знаков - от восприятия, мифа, искусства до науки. Вместе с тем П. Рикер придает понятию «символ» более широкий смысл, чем те авторы, которые, исходя из латинской риторики или неоплатонической традиции, сводят символ к аналогии. П. Рикер называет символом всякую структуру значений, где один смысл, прямой, первичный, буквальный, означает одновременно и другой смысл, косвенный, вторичный, иносказательный, который может быть понят лишь через первый. Такие выражения с двойным смыслом Р. Барт назвал «вторичной семиологической структурой», «метаязыком» или «идеологией». Однако попытка Р. Барта жестко разграничить уровни денотации и коннотации не увенчалась успехом, поскольку денотация оказалась лишь последней из возможных коннотаций, а культура предстала в виде сложного переплетения различных метаязыков (Барт, 1994).

Современные теории метафоры отошли от ее традиционного понимания в качестве свернутого сравнения, строящегося за счет сравнения двух смыслов - прямого, буквального и косвенного, переносного: например, «щечки - розы, зубки - кораллы». В случае свернутого сравнения механизм соотнесения значений видится как выделение двух классов объектов («щеки» и «розы») и нахождение между ними признаков, присущих им обоим («шелковистость», «розовый цвет», «нежность» и т. п.), которые лишь подразумаваются (что и отличает метафору от сравнения: «щечки похожи своей шелковистостью и т. п. на розы»). Однако факт появления новых метафор заставил исследователей посмотреть на метафору не как на сходство объектов, а как на взаимодействие смыслов, поскольку, во-первых, не всегда удается обнаружить общие признаки объектов («хрустальная печаль» сравнение хрусталя и печали оказывается весьма проблематичным), и, во-вторых, порой вообще нет необходимости в нахождении объекта сравнения («мертвый голос», «черное солнце»).

Проблематизация самого понятия метафоры привела к возникновению ряда теорий метафоры. Мы остановимся на рассмотрении тех из них, которые наиболее существенны для логики нашего изложения (Теория метафоры, 1990).

В теории метафоры Дерика Бикертона выделяется четыре класса выражений, образованных связью знака (X) с атрибутом (Y). По типу «присваиваемых атрибутов» выражения распадаются на:

- буквальные («черная кошка») присвоение атрибута типично;

- постоянные («серебро волос») присвоение атрибута устойчиво в лексике культуры; 
- разовые («гиацинтовый Пегас», «смычок черноголосый») - авторское присвоение атрибута;

- бессмысленные («промедление пьет учетверенность») - присвоение атрибутов случайно.

Первые (буквальные) выражения либо вообще не рассматриваются как метафоры, либо характеризуются как «стертые» метафоры («золотые руки»), а последние (бессмысленные), как правило, в языке не приживаются. Поэтому наибольшей «зоной роста» обладает авторское присвоение атрибутов, которое можно рассматривать как «лабораторию», из которой новые метафоры проникают в широкий и устойчивый пласт привычных метафор («голубая луна», например).

Важно отметить, что сам процесс метафоризации, если смотреть на него сквозь призму теории Д. Бикертона, расслаивается и метафоризация предстает как сложный, в той или иной степени творческий процесс. Это важно не только для оценки поэтического и художественного творчества в сфере искусства, но и для понимания степени личностного вложения при появлении метафоры в процесс психотерапии, о чем речь пойдет ниже. При этом построение авторской «развернутой метафоры» представляется наиболее интересным. Так, символическая поэзия и художественная проза могут быть рассмотрены как варианты такого авторского использования развернутой метафоры. В этом случае даже целое произведение может быть рассмотрено как единая метафора. Например, роман Р. Хаггарда «Она» можно рассматривать как метафору психических процессов взаимодей- ствия эго-комплекса и бессознательного по К.Г. Юнгу; при этом образы в романе (главные и второстепенные персонажи, стадии путешествия героев, описания местностей и природных явлений), если использовать терминологию льежской «группы мю», будут являться «неполными метафорами» (metaphora in absentia), смысл которых может быть реконструирован только при знакомстве с системой архетипических образов К.Г. Юнга.

Подобные неполные метафоры были весьма подробно рассмотрены исследователями символической поэзии, которые чаще всего отождествляли неполную метафору с символом. Б. Вейнберг (Weinberg, 1966), анализируя поэзию символистов, в частности «Лебедя» Ш. Бодлера и «Пьяный корабль» А. Рембо, описывает символический метод как особый случай структурной (а не эпизодической) метафоры, в которой одна часть (символизирующее) дана явно и подробно, а вторая (символизируемое) подразумевается. Переход ко второй половине метафоры и ее реконструкция базируются, во-первых, на наличии в символизирующем плане специальных «знаков и указаний» и, во-вторых, на «идентичности эмоций» по поводу обеих частей.

Однако гораздо большие возможности для неожиданных сравнений предоставляет более полная метафора, в которой хотя бы частично дан и второй семантический ряд. Рассмотрим пример: «А с утра все тот же бег снегов и облаков, и чуть выше - проглядывающее сквозь простыни солнце» (Жакопетти). В этом случае реконструкция второго смыслового 
ряда выстраивается благодаря присутствующему в тексте слову «простыни» и сопоставление двух смысловых рядов оказывается возможным благодаря их своеобразному «перехлесту». Реконструкция может выглядеть так:

солнце - снег + облака $=($ природа $)$

$($ спящий $)-$ простыни $=($ человек $)$.

Для нас именно авторская «неполная метафора», план выражения которой при этом наиболее «развернут», представляет наибольший интерес. Такие метафоры, как будет показано ниже, составляют особый «пласт» субъектности и наиболее отчетливо проступают на определенном этапе психотерапии в говорении клиента и терапевта.

Символическое отношение как особый тип отношения, не сводимый к знаковому и метафорическому

Рассмотренные выше представления о символическом отношении как условном или иконическом знаке или неполной метафоре не будут полны, если не остановиться на понимании символа в качестве соединения двух разнокачественных сторон в единое целое. Исторически подобное представление о символе можно найти уже у Платона, а в максимально наглядной форме данное представление было развито в жанре «живописной поэзии» (picta poesis).

Смешанное искусство «живописной поэзии» (XVI-XVII вв.) состояло из жанра эмблемы (emblemata signa) и жанра девиза (symbolum). Оба они практиковались как специфическая «наука двора», преследуя двоякую цель: развлекать и назидать. Их структура включала в себя рису- нок и текст. Трехчастная эмблема состояла из inscriptio, «надписи» короткой фразы, обычно на латыни, pictura - рисунка под ней и subscriptio, «подписи» - развернутого текста внизу, поясняющего рисунок и его связь с надписью. Двухчастный девиз же состоял из короткой текстовой фразы и рисунка. При этом в девизе текст и рисунок, дополняя друг друга, порождали смысл, которого нет ни в рисунке, ни в тексте по отдельности, рисунок «показывает» одну часть замысла, а слова - «другую», в эмблеме же текст и рисунок имеют равнозначные смыслы, которые скорее усиливают, чем дополняют друг друга. Позднее рисунки стали называться эмблемами, а надписи к ним - символами (что характерно и для первой книги эмблем в России «Эмблемы и символы», впервые изданной в 1705 г. в Амстердаме по заказу Петра I).

В отличие от знаков и метафор, предполагающих коннотирование как своеобразное «дополнительное» действие, которое может быть как устранено (при буквальном понимании), так и продолжено в принципе до бесконечности, девиз предполагает «сращение» образа и слова в одно нерасторжимое целое.

В связи с этим нужно упомянуть, что исторически древнегреческий символ представлял собой часть разломленного пополам черепка или разрубленной надвое монеты. Эти половинки имелись у двух людей, заключивших «союз гостеприимства», распространявшийся и на их детей, которые могли унаследовать «симболоны». Также, например, интересно отметить, что у Платона в «Пире» Аристофан говорит о человеке 
как об «антропон симболон» (Platonis, 1905-1913) - «человеческой половинке» и о любви как жажде целостности и стремлении к ней. Для Аристотеля мужское и женское, звук («фоне») и состояние души («психе») - это также симболоны (Бибихин, 2007). Вполне очевидно, что при таком понимании понятие символа нельзя уже заменить понятиями знака или метафоры.

Подобное же понимание символа можно встретить и в современных текстах. Например, М.К. Мамардашвили в «Лекциях о Прусте» трактовал символическое действие, ссылаясь на древнегреческое понимание символа как расколотого надвое целого. Для М.К. Мамардашвили основная тема «Поисков утраченного времени» М. Пруста - это тема ищущих встречи двух половин, бывших когда-то единым впечатлением, а потом распавшихся: одна половина слилась с физическим объектом (цветами боярышника, печеньем «мадлен» и т. п.), а вторая - осталась в душе, но не может дать понимания до тех пор, пока не встретится и не срастется с утраченной половинкой. Согласно М.К. Мамардашвили, для Пруста человеческая душа в большинстве своем состоит как раз из таких беспорядочно перемешанных половинок, поиск дополнения к которым и есть «поиск утраченного времени» (Мамардашвили, 1995).

Структура так понимаемого символа конституирована уникальностью «нехватки», которую надо восполнить единственно возможным образом. В отличие от знака и метафоры, провоцирующих «перспективное» видение все новых и новых семантических ходов, символ-«обло- мок» - залог единственной уникальной встречи.

Приведенная интерпретация позволяет уточнить характеристики символической структуры, введя понятия «нехватки» и «целостности», которая в качестве цели объединяет и объясняет стороны отношения, а в качестве полноты смысла исключает все другие возможности соединения.

\section{В поисках онтологческой вертикали}

\section{Символ как способ познания истины: логика уподобления}

Не только в поэтике, риторике и семиотике, но и в гносеологии и онтологии понятие символа имеет долгую историю, на протяжении которой символ отождествлялся то со знаком, то с метафорой. На наш взгляд, имеет смысл проследить логику трансформации этого понятия у разных авторов в разное время.

Начиная с XIX в. стало принятым отождествлять символ с «таинственным знаком», или «иероглифом». Х.-Г. Гадамер пишет, что подобное отождествление укрепилось на исходе XVIII в., когда словом «символ» стали называть не просто знаковое обозначение или значащее замещение, а представление о метафизической связи видимого и невидимого (Гадамер, 1988). По мнению Х.-Г. Гадамера, такое понимание символа оказалось возможным в период, когда пали идеалы Просвещения и, в первую очередь, идеал рациональности (однозначности и «прозрачности» для умопостижения). Наступающая эпоха романтизма стала включать в понятие символа признаки многозначности и неопределенности, что позволило выделить и 
возвеличить символическое как наиболее соответствующее духу времени, противопоставив аллегорическому, ставшему пониматься как однозначно связанное со своим значением. Эта однозначность, в свою очередь, истолковывалась как привнесенная извне, т. е. связывающая образ и идею условно (конвенционально), в то время как смысловая поливалентность символа расценивалась как его «внутренняя» характеристика, обеспеченная бесконечной «игрой» феноменального и ноуменального.

В каком-то смысле противопоставление многозначного символа и однозначной аллегории явилось квинтэссенцией противопоставления идеалов и принципов романтизма и Просвещения. В аллегории стала доминировать культурологическая составляющая (историческая, фольклорная, мифологическая), в символе же стали видеть представительство ноуменального мира в мире явлений. Поэтому если аллегорические способы выражения могли различаться и конкурировать между собой, то символы понимались как предельно неконвенциональные соединения ноумена и феномена.

В западной философской традиции подобное понимание символа колебалось между двумя полюсами: 1) гегелевским представлением о символе как «родственном», но неадекватном выражении идеи в образе и 2) шеллингианским, полагающим их тождество.

Для Г.В.Ф. Гегеля символизм являлся первой, а потому наименее совершенной формой искусства. В «Лекциях по эстетике» символ определяется им как образ, который сам по себе взятый вызывает в нас представление о чем-то непосредственно существующем на основании «родственности», но без «полного взаимослияния» значения и выражения. Например, «лисица - символ хитрости», «круг - символ вечности», «лев символ силы» (Гегель, 1938). Несоответствие между образом и идеей возникает из-за того, что идея еще неопределенна, абстрактна, одностороння и потому находит образ не внутри себя, а берет его извне. Эта игра чуждости и родственности позволяет идее преодолеть символическую форму искусства, достигнув акмэ в классической форме (гармония идеи и образа) и исчерпав свое художественное инобытие в форме романтической (распад образа, который, переставая вмещать в себя идею, начинает мешать ее саморазвитию).

Позиция Г.В.Ф. Гегеля была ближе духу Просвещения, Ф.В. Шеллинг же во многом опирался на немецкую мистическую традицию. Для романтиков гегелевский подход был не столько манифестом, сколько критикой, для них ключевым стало шеллингианское представление о символе как совпадении явления и смысла.

\section{Символ как самостоятельный орга- низм: логика отождествления}

Для Ф.В. Шеллинга «абсолютная неразличимость» (Шеллинг, 1966), полное слияние общего (идеального) и особенного (феноменального) органично. Это не отношение обозначения или репрезентации (представительства), а существование живого организма, смысл и телесное бытие которого совпадают. Подобное понимание позволило ему говорить о 
произведениях искусства как об организмах (Gewachse - «растениях»), более высокоразвитых и автономных, чем обычные биологические организмы. Мифы также являются организмами, их не следует считать ни пустыми образами (т. е. фикциями языка), ни персонификациями стихий (аллегориями). Символическое, оказываясь синонимом органического, противостоит схематическому (когда общее обозначает особенное) и аллегорическому (когда, наоборот, особенное обозначает общее) и образуется через их синтез. Символ оказывается организмом (осмысленным бытием), а организм символом, поскольку в нем совпадает общее (род, идеальное) и особенное (особь, феноменально данное). Романтикам такое понимание символического было ближе, поскольку образ они воспринимали сращенным (конкретным, от лат. concrescere срастаться) со смыслом. При таком ракурсе Голубой цветок Новалиса оказывался не риторической фигурой (метафорой или аллегорией), а живым ликом Вечной Женственности.

Однако отождествление как символический принцип порождает ряд проблем, главная из которых - это проблема различения сторон отношения. Тождество упирается в неустранимость инаковости, поскольку, как весьма точно выразился А.Ф. Лосев, «отождествлять можно только то, что различно» (Лосев, 1978, c. 128). Поскольку же базовой чертой символической структуры является наличие сторон отношения, то абсолютное тождество приводит к ее уничтожению: либо одна из сторон отношения «поглощает» другую, либо в действие включается механизм различения и стороны распадаются.

\section{Символ как орудие изменения: ло- гика встречи}

Как уже отмечалось выше, символическое отношение, понимаемое как уподобление сторон и как их отождествление, можно дополнить пониманием его как соединения двух разных сторон в единое целое. В качестве репрезентативных иллюстраций целесообразно рассмотреть представления о символизме С.Н. Булгакова и П.А. Флоренского в русской религиозной традиции, сравнив их с представлениями одного из наиболее ярких представителей западной философской мысли - М. Хайдеггера.

И для С.Н. Булгакова, и для П.А. Флоренского как религиозных мыслителей символ оказывается тем «увеличительным стеклом», которое позволяет выявить сложную динамику взаимоотношений онтологически различных природ: во-первых, тварной и нетварной; а во-вторых, небесной (святой и ангельской) и земной. Однако сам способ отношения описывается ими по-разному. Если для первого из них символ это соприсутствие, как бы соположение, «соединение двух естеств» (Булгаков, 1953), то для второго это их синергия. «Неслиянность и нераздельность» сторон таким образом понимаемого символа разворачивается у П.А. Флоренского в концепцию всеобъемлющего энергийного символизма, опирающегося на богословское учение св. Григория Паламы о божественных энергиях. Энергии разных онтологических уровней соучаствуют: высшие просветляют, 
освящают и упорядочивают низшие силы, которые, однако, оказываются не просто пассивными передатчиками, поскольку они выявляют свое бытие в таком сотрудничестве. Поэтому для того, чтобы стихии чувственного мира (например, краски, дерево, изобразительная техника в иконописи) пришли в должное состояние и раскрыли свои возможности, в должное состоянии необходимо привести душу и тело (психические и телесные стихии) мастера. Его психические и телесные энергии очищаются постом и молитвой, освящаются благодатью, и только в благодатном состоянии создается икона-символ как органическое сращение энергий двух миров. Особый акцент следует сделать именно на диалектическом удержании «неслиянности и нераздельности» - формуле, найденной в свое время Св. Отцами на II Вселенском соборе и включенной в христианские догматические положения как предостережение от христологических ересей. Не случайно поэтому С.Н. Булгаков в качестве примера наивысшего символа приводит соединение божественной и человеческой природ в Христе, когда ни первая не поглощает последнюю (как в монофизитской ереси), ни вторая не вытесняет первую (как в арианстве). Однако и сам человек в христианской традиции представляет собой сложное органическое «сращение» духовного и телесного начал, дисгармония в отношениях которых приводит к различным религиозным и экзистенциальным проблемам.

У М. Хайдеггера в «Истоке художественного творения» художественное творение есть символ. В отличие от чистой служебности, дельности вещи художественное творение имеет основание своего бытия в воздвижении своего мира и хранении его спора с землей. Причем спор это углубленная проникновенность взаимной приверженности спорящих сил друг другу. Творение, будучи явленностью, алетейей, оказывается спором за единство мира и земли, за единство непотаенности (мира, Welt) и сокрытости (земли, Erde), просветления и затворения. Удержание, хранение спора - это хранение расходящихся до противостояния друг другу спорящих сторон таким образом, что только в этом споре земля впервые становится землей, а мир - миром. М. Хайдеггер также называет этот спор спором меры и безмерности, предела и беспредельного, пифагорейских единицы и двоицы. Но, говоря об их едином основании, он явно акцентирует их противостояние, их «диалектику», понимаемую в первоначальном смысле как удержание разнонаправленных голосов внутри единства спора, позволяющего самоопределиться каждому из них. Подчеркнутая инаковость мира и земли позволяет им вступать в драматические отношения, исход которых не предопределен, и дает увидеть произведение искусства не как нечто покоящееся, а как ринг двух сил, готовых как к «диалогу», так и к уничтожению друг друга.

Таким образом, символическое отношение можно выделить как некий особый тип соединения двух разнокачественных сторон отношения в единое целое, тем самым отличив его от процессов означения и метафоризации. 


\section{Субъектное отношение: историко-психологический анализ}

\section{Орудия развития субъектности}

\section{Знак как орудие развития высших} психических функций

Понятие высших психических функций - одно из базовых понятий современной психологии. Это понятие было предложено Л.С. Выготским и далее развито А.Р. Лурией, А.Н. Леонтьевым, А.В. Запорожцем, Д.Б. Элькониным, П.Я. Гальпериным и др. Высшие психические функции специфически человеческая форма психики - обязаны своим развитием знаку: одним из неотъемлемых свойств высших психических функций, наряду с социальностью происхождения, прижизненным формированием, произвольностью (сознательностью выполнения) по способу осуществления, является опосредованность знаком, т. е. семиотическая опосредованность.

Отечественная психологическая традиция полагает, что первоначально высшие психические функции существуют как форма семиотически опосредованного взаимодействия между людьми, т. е. интерпсихического процесса, в контексте их совместной деятельности и позже они преобразуются в интерпсихологическую функцию. Этот процесс носит название интериоризации.

Процесс интериоризации знаков как носителей значений, понимаемых предельно широко (как речь, образ, схема действия, представление о норме поведения, схемы, карты, формулы и чертежи, системы символических образов, язык искус- ства - живописи и архитектуры, танца и пантомимы и т. д.), участвует в преобразовании «натуральной психики» в обусловленную, культурную. При этом Л.С. Выготский концентрируется на изучении вербальных знаков, значений и выделяет три основные ступени развития значения слова.

На первой стадии развития значением слова «является не определенное до конца, не оформленное синкретическое сцепление предметов, так или иначе связывавшихся друг с другом в представлении ребенка в один слитный образ». Вторую ступень он называет «мышлением в комплексах». Теперь обобщение, объединение предметов в группы ребенок производит на основе их объективных связей. «Комплексное мышление есть уже связное мышление и одновременно объективное мышление. Это те две новые существенные черты, которые поднимают его над предыдущей ступенью. Вместе с тем и эта связность, и эта объективность еще не являются той связностью, характерной для мышления в понятиях, к которому приходит подросток.»

Основой построения комплексов является конкретная ситуативная связь. Эта стадия развития понятий подразделяется на пять форм, различающихся по типу составляющих их комплексов-обобщений. Особого внимания заслуживает пятая форма развития комплексов - псевдопонятия. Этот комплекс в функциональном отношении уже эквивалентен понятию, но построен по иным законам. Ребенок строит такой комплекс на основе конкретных ситуативных связей, однако его употребление в 
конкретной ситуации совпадает с использованием понятий.

На третьей ступени развития значений появляются собственно понятия. Здесь из образа конкретного предмета вычленяется часть признаков, и именно эти признаки выступают особенно рельефно в сознании ребенка. Это обобщение, созданное ребенком на основе максимального сходства, одновременно и более бедный, и более богатый процесс, чем псевдопонятия (Выготский, 1982).

На этой ступени развития впервые четко проступают процессы абстракции, позволяющие выделить одни признаки и игнорировать другие, само же понятие образуется тогда, когда ряд абстрагированных признаков вновь синтезируется. Решающую роль в образовании понятий играет слово как средство направления внимания на соответствующий признак, как средство абстрагирования. Здесь роль слова (значение словесного знака) совсем другая, чем на уровне комплексов.

В терминологии Л.С. Выготского это «житейские понятия», которые являются представлениями, идущими от конкретного к абстрактному. Они спонтанны и могут в должной мере даже не артикулироваться ребенком, они у него просто «есть» как своеобразные классификаторы. Путь образования научных понятий путь от абстрактного к конкретному (сверху вниз) - противоположен пути образования житейских понятий. Благодаря научным понятиям человек осознает те свойства предмета, которые не представлены в конкретной ситуации.

Л.С. Выготский искал минимальную единицу анализа вербального мышления, которая несла бы в себе все его свойства. Он проследил линии развития обобщения и абстрагирования (синкрет - комплекс - житейское понятие - научное понятие) и выделил динамическую единицу значение слова. Анализируя развитие научных понятий, Л.С. Выготский среди основных выделяет такие их свойства, как осознанность (системность) и произвольность.

В.П. Серкин указывает, что, хотя Л.С. Выготский имел в виду значение слова, его теоретические выводы могут быть использованы с соответствующими поправками для анализа развития любых форм значения. Такая процедура возможна, поскольку в основе развития форм значений лежат общие психические образования и эти формы не развиваются изолированно, так что при рассмотрении развития любой из них исследователь должен обратиться к общим закономерностям их развития (Серкин, 2008).

Понимая знак предельно широко, включая в это понятие наряду с вербальными значениями также системы символических образов, язык литературы и искусства, схемы и пр., попробуем распространить методологическое представление о средствах опосредования как механизме развития психического и на метафорический, и на символический образ. В этом случае метафорические и символические образы наряду со знаками могут служить средством кардинальных преобразований человеческой психики и развития сознания.

\section{Смысл как базовый элемент сознания}

В деятельностном подходе, развиваемом школой А.Н. Леонтьева, 
концептуальная схема сознания, его структура, оказывается обогащенной таким компонентом, как личностный смысл. В системной организации человеческого сознания выделяются следующие образующие этой системы: значение, личностный смысл и чувственная ткань.

Под личностным смыслом А.Н. Леонтьев предлагает понимать отношение субъекта к миру, выраженному в значениях, т. е. как бы «значение значения» для личности, неразрывно связанное с ее мотивами, с ее общей направленностью. В этом понятии отражено отношение к миру активного субъекта. Введение понятия «личностный смысл» обусловлено необходимостью учитывать функционирование значений как элементов общественного сознания, с одной стороны, и индивидуального, с другой.

Поскольку образующие сознание процессы выступают как единое функциональное целое, то, как отмечает А.Н. Леонтьев, одна из сторон движения значений в сознании конкретных индивидов состоит в возвращении их к чувственной предметности мира, другая же сторона состоит в той особой субъективности, которая выражается в приобретаемой ими «пристрастности», т. е. в связи с личностным смыслом.

Развивая теорию сознания А.Н. Леонтьева, Д.А. Леонтьев предлагает считать понятие «смысл» родовым по отношению к понятию «значение». Такая точка зрения обосновывается тем, что отношение человека к объектам внешнего мира, наиболее глубинные структуры субъективного опыта даны ему именно в виде смысловых отношений.
Формой проявления личностного смысла могут выступать эмоциональная окраска того или иного объекта, неосознаваемые установки или готовности. Осознанный личностный смысл подразумевает представленность его субъекту в некоторых социально нормированных единицах, главным образом - в языковых значениях. При этом в силу меньшей, чем у «знакового», конвенционального языка, опирающегося на общепринятые и нормативно фиксированные значения, определенности и в силу большей вариабельности, индивидуальности элементов язык, выражающий личностный смысл, тяготеет к образности.

Таким образом, символизацию и метафоризацию мы будем рассматривать как средства развития и преобразования психического через отражение, выражение и преобразование личностных смыслов субъекта.

\section{Психотерапия: от знакового языка значений, через метафоризацию к символизации}

Отношение между теорией и практикой в сфере психотерапии-консультирования, отношение практиков к теоретическим концепциям и моделям оформляется двояким образом - либо как репродуктивное, либо как продуктивное отношение. В первом случае акцент ставится на воспроизведение в практике той или иной традиции психологического теоретизирования, того или иного психотерапевтического мифа (от психоаналитического до трансперсонального).

Во втором случае акцент переносится на создание, порождение нового способа новой формы такого 
теоретизирования. Если репродуктивное отношение между теорией и практикой, между психологией и психотерапией-консультированием обеспечивает существование традиционных школ и направлений в этой сфеpe, то продуктивное отношение приводит к возникновению новых разновидностей психотерапии-консультирования. В практической психологии эти отношения представлены весьма полно: наряду с направлениями и школами, традиционно существующими десятки лет, мы видим возникновение десятков, а теперь уже и сотен новых разновидностей психотерапии-консультирования.

\section{Означение в психотерапии}

Как нами уже отмечалось выше, процесс означения предполагает возможность порождения различных коннотативных систем, или, в терминологии Р. Барта, «мифов», или «идеологий».

В вербальной терапии в речи клиента изначально представлена только интерпретация клиентом своих или чужих поступков, действий, реакций как несущих какой-либо смысл. До и вне терапии клиент уже выделил это содержание как значимый, заслуживающий внимания «факт». Этап же первичного означения, как правило, в жизни клиента автоматизирован, «свернут». Сознанию представлен только результат «надстройки», переработки «сырого» материала первичного означения в ходе вторичного означения. К психотерапевту клиент идет уже с «мифами», а вовсе не с фактами.

Приведем пример содержания, с которым клиентка могла бы прийти на прием к психотерапевту: женщина замечает, что ее муж возвращается домой раздраженным; состояние мужа означается и понимается как раздражение (первичное означение, денотация). Исходя из этого понимания, клиентка делает вывод, что она больше не интересует своего мужа, что он охладел к ней, тяготится ее присутствием и, возможно, завел любовницу (вторичное означение, коннотация). В данном случае важно, что интерпретации, домысливания не следуют непосредственно из того, что воспринято, а «надстраиваются» дополнительно. В принципе форма и материал «фундамента» не определяют однозначно форму и материал «надстройки», здесь имеется большое количество степеней свободы.

Клиент предлагает консультанту миф как результат вторичного (или n-го означения), и в задачу психотерапевта входит «распутать клубок» субъективных интерпретаций клиента, добраться до его сердцевины неозначенных содержаний (еще не опредмеченных), альтернативных смыслов. Вместе с клиентом психотерапевт переозначивает элементы опыта клиента, если угодно, переименовывает их и строит другой, более аутентичный жизненным фактам, реальному опыту клиента миф. Миф в данном случае представляется нам целостным аффективно-когнитивным образованием, в котором отражаются потребности и интересы личности, ее мотивы и ценности, установки и убеждения.

Таким образом, в вербальной терапии общение, как правило, начинается на уровне мифа и только потом, с углублением контакта «опус- 
кается» до уровня более или менее «объективных» фактов внешней или внутренней жизни субъекта.

Чтобы высвободить клиента из «кокона» его мифа, сотканного из многослойных интерпретаций, консультант обращается к актуальным эмоциональным проявлениям как к единственно достойной внимания исходной субъективной реальности клиента, «входит в резонанс» с ней, выводя ее тем самым вовне. До того, как чувство будет четко артикулировано, он избегает какой-либо оценочности в форме интерпретации, выяснения причин его появления, т. е. каких-либо вторичных означений.

На начальном этапе работы неосознаваемые содержания клиента циркулируют в поле психотерапии в полифонии смыслов наряду с осознаваемыми, однако на ином уровне (интуитивном, до-рефлексивном). Если выраженное консультантом содержание резонирует с таковым у клиента, то происходят изменения, которые можно квалифицировать как движение клиента по пути самопонимания. Однако наряду с направленностью вектора означения от консультанта к клиенту имеет место и встречно направленное движение от клиента к консультанту. Облекая свое внутреннее содержание в определенную форму и вынося вовне, клиент разотождествляется с ним, выносит его за пределы своей субъективности. Будучи «подтвержденным», принятым консультантом, это содержание становится более понятным и определенным, оно предстает перед участниками процесса, и с ним возможна дальнейшая работа. В невербальной терапии также присутствуют эти два вектора направленнос- ти первичного означения, однако в роли консультанта выступает художественный продукт. Так или иначе процесс означения в разговорной терапии происходит в тесном взаимодействии консультанта и клиента в отличие от процесса первичного означения в невербальной терапии, происходящего главным образом в интерсубъективном пространстве самого клиента, где главная задача консультанта состоит в создании наиболее благоприятных условий для такого контакта.

В невербальной терапии общение клиента и терапевта также начинается на уровне мифа и в дальнейшем происходит «развенчание» этого мифа, однако это происходит иначе, нежели в вербальной терапии. Здесь первичное и вторичное означение можно дифференцировать гораздо более отчетливо, избрав формальные критерии. Так, первичное означение можно представить как длящийся во времени процесс создания художественного продукта (рисунка, скульптуры, танца, песенного или музыкального мотива и пр.). Например, клиента просят отразить в рисунке (поделке, танце) свои актуальные переживания, чувства. В данном случае результат означения материален, отчетлив, явлен (в отличие от более эфемерного результата означения в вербальной терапии). Кроме того, здесь процесс означения более длителен, растянут во времени, менее автоматизирован (более осознан), нежели его аналог в вербальной терапии. Мы полагаем, что удлинение, разворачивание, растягивание процесса первичного означения во времени является одним из значимых механизмов лечебного воздействия 
невербальной терапии. Кроме того, означение в этом случае происходит как бы «с чистого листа», заново благодаря необычным условиям, новым ощущениям, новому материалу, с которым клиент работает.

Все эти обстоятельства приводят к тому, что доминирующие при работе с языковым текстом многочисленные наслоения предыдущих осмыслений и интерпретаций теряют свою жесткость, незыблемость и однозначность, проступают альтернативные значения и смыслы, появляется возможность прикоснуться к истокам содержаний, еще не захваченных сетью значений, существенно возрастает свобода выбора. Вот чем, на наш взгляд, объясняются многочисленные случаи появления неожиданных для самого субъекта содержаний в его художественной продукции. Эти содержания возникают как результат работы интуиции и не могут быть объяснены с точки зрения линейной логики.

C самого начала продукт первичного невербального означения таит в себе загадку как для терапевта, так и для самого клиента. Этим он отличен от продукта вербального клиентского дискурса, который кажется клиенту вполне очевидным, понятным, однозначным. Так, изначально усматривая загадку, тайну в своем художественном произведении, клиент более естественно входит в терапевтический альянс с целью эту тайну исследовать и понять, нежели в ситуации вербальной терапии, где он, скорее всего, занимает более пассивную позицию, ожидая от терапевта советов, указаний и директив. В невербальной терапии позиция клиента оказывается более зрелой, нежели в вербальной, где происходит перекладывание клиентом ответственности за процесс исцеления на терапевта.

Продукт первичного означения в невербальной терапии начинает впоследствии жить своей жизнью, занимая законное место полноценного участника психотерапевтического процесса, - диадическое взаимодействие становится триадическим, терапевтический диалог преобразуется в триалог.

Третий «участник» психотерапевтического процесса представляет собой во многом непознанное (и, как правило, ресурсное) альтер эго клиента, зашифрованное, но в принцип доступное для понимания. Верным кодом расшифровки такого альтер эго обладает только сам клиент, что способствует возрастанию ощущения безопасности его самовыражения в терапевтическом пространстве. В то же время в вербальной терапии вынесение своих внутренних содержаний в конвенциональных знаках, значение которых очевидно, небезопасно и может запускать защитные механизмы, призванные исказить, переиначить, завуалировать, скрыть первоначальные смыслы, так что терапевт будет вынужден угадывать эти смыслы, преодолевая сопротивление клиента.

Таким образом, мы полагаем, что в режиме невербальной экспрессии альтернативные означения внутренних содержаний клиента начнут проявляться раньше и более отчетливо в виде альтернативных неожиданных смыслов, нежели в режиме вербальной экспрессии, конечно, при условии, что клиент включится в работу 
и примет парадигму невербальной терапии.

Благодаря специфике художественной экспрессии по сравнению с вербальным аналогом ее продукт сохраняет свои очертания в ходе дальнейшего обсуждения, работы с ним. Эти очертания могут меняться, но только в результате сознательного намерения клиента и (или) терапевта (дополнение рисунка, его изменения). Артикулированное чувство контроля над ситуацией, авторства и произвольности вносимых изменений (интенция к которым может лежать за пределами сознания) создает у клиента ощущение «твердой почвы под ногами», опоры, контрастирующей с возможной неопределенностью словесного обсуждения.

В невербальной терапии клиент получает опыт авторства в высказывании неосознаваемых до сих пор содержаний и через этот опыт присваивает содержания. Например, клиент ощущает себя одновременно и субъектом, и инструментом экспрессии (он сам рисует и одновременно как будто что-то рисует «из него», «от его имени»). В вербальной же терапии продукт - текст обладает свойством текучести, к нему сложно вернуться, он ускользает, за него сложно «зацепиться», что иногда создает у клиента ощущение тревожной неопределенности, бесполезного пустого разговора «ни о чем». Кроме того, звучащие порой в дискурсе клиента альтернативные смыслы «заглушаются» доминирующими смыслами. Клиент, естественно, ощущает себя автором собственной речи, однако речь в данном случае выступает как инструмент выражения доминирующих смыслов. Таким образом, клиент в данном случае не получает опыта авторства в выражении альтернативных смыслов, не замечая их появления.

\section{Метафоризачия в психотерапии}

В настоящее время в литературе, посвященной исследованию механизмов и действующих сил психотерапии, все больше внимания уделяется образной и метафорической составляющей коммуникации. Метафорическая коммуникация (общение с использованием метафор) занимает видное место в гештальттерапии, НЛП, гуманистически и экзистенциально ориентированных подходах, эриксонианстве (Калина, 1997), а также сказкотерапии, песочной терапии, при толковании сновидений и т. д.

Хотя метафоры в психотерапии используются давно и широко обсуждаются вопросы их образования, эффективности использования, роли и функции в психотерапии (Баркер, 1995; Кроль, 1999; Леоненко, Тимошенко, 2005), специальных исследований, посвященных изучению психологических механизмов функционирования метафор в психотерапии, фактически нет. Большинство литературных источников, посвященных теме метафоры, оказываются замкнутыми на психотерапию, более того, на психотерапевтическую практику. Тексты, как правило, изобилуют клиническими примерами, за которыми не следуют общепсихологические выводы и обобщения. Редко кто из авторов решается выйти в своих рассуждениях за рамки психотерапии. Редкие и эпизодические выдержки из иных областей гуманитарного (философского, 
филологического, социологического) знания в качестве отступлений от основной, психотерапевтической темы слабо связаны с основным текстом (Калина, 1997; Леоненко, Тимошенко, 2005).

В свете вышесказанного уместно задать вопрос о психологических механизмах, обеспечивающих психотерапевтические достоинства метафорической (образной) коммуникации.

Еще 3. Фрейд отмечал, что образное мышление и использование образов в общении гораздо ближе к бессознательным процессам, нежели знаковое, словесное мышление и общение, что оно и фило-, и онтогенетически старше, чем последнее.

Д. Эдвардс приводит концепцию Д. Шаверьен, которая считает, что, когда клиент взаимодействует с образом, воплощающим его чувства, становятся возможны изменения (Edwards, 2004). Однако не все образы одинаково эффективны в этом отношении, не все стимулируют изменения. Образы можно разделить на «воплощенные» и «схематичные» (или «невоплощенные» в переводе Копытина).

Схематичные образы скорее описывают чувства клиента, нежели выражают их. Картина в данном случае служит иллюстрацией переживания клиента, а не воплощением этого переживания, т. е. нельзя говорить об эмоциональном инвестировании в данный образ, он уже представляет собой некую рефлексивную когнитивную интерпретацию переживания. В этом случае клиент способен заранее предугадать результаты своего творческого процесса.

Этот класс образов, по-видимому, можно отнести к образам-знакам в нашей классификации. Они описывают определенные психические проявления, и цель этого описания, как нам представляется, прояснение того, что знает клиент, психотерапевту, т. е. интерпсихическая коммуникация. «Невоплощенные» образы выражают связанные с переносом чувства клиента, тогда как в «воплощенных» образах актуализируется более широкий пласт раннего и текущего опыта клиента, не ограниченного переносными чувствами. В случае воплощенных образов не имеет значения изначальное намерение клиента: независимо от того, что клиент ожидал нарисовать, получиться может совсем иное.

Особое внимание Д. Шаверьен уделяет тем отношениям, которые устанавливаются между клиентом и его творческим продуктом в случае «воплощенных» образов, приобретающие особое значение в глазах клиента, оказывает особое воздействие на него. Эти образы заключают в себе аффекты со всей их энергией и обладают особой способностью, потенциалом воздействия на автора изображения.

Образ становится «средством воплощения аффектов» клиента, продолжением его переживаний, их частью вместо того, чтобы быть только отражением или описанием (как в случае «схематичных» образов). «Воплощенные» образы несут в себе сильнейший эмоциональный заряд, и по этой причине встреча с ними может быть болезненной, отмечает С. Скейфи (Скейфи, 2001).

Однако нельзя отрицать значимость «схематичных» образов. Они также имеют определенную психотерапевтическую ценность: они могут 
предшествовать более поздним эмоционально насыщенным образам, т. е. в данном случае речь идет об этапах работы с образами другого плана, нежели в перечисленных ранее; появление схематичных образов предшествует во времени появлению образов воплощенных, несущих сильный эмоциональный заряд и непредсказуемых по содержанию.

Вслед за Н.Ф. Калиной (Калина, 1997) мы рассматриваем психотерапию как преимущественно метафорическую коммуникацию. При этом не всякая метафора обладает психотерапевтической функцией (собственно функцией метафоризации). Так, общеупотребительные, клишированные языковые (художественные и научные) метафоры (например, «течение жизни», «цветение юности», «туманное будущее», «черная дыра», «пустое множество» и т. п.) не образуют новые целостности в индивидуальном сознании, воспринимаются человеком не как метафоры, а как значения (знаки). Такие квазиметафоры выполняют функцию означения субъектности клиента, но не продвигают эту субъектность на качественно новый (более целостный) уровень.

Данная особенность метафор в свое время была описана Ю.М. Лотманом (Лотман, 1992): метафоры существуют в диапазоне «новаторских» и «тривиальных» смыслопорождающих структур, они подвержены процессам «омоложения» и «старения», движения между полюсами «знак» и (собственно) «метафора». В психотерапевтическом общении порождение новаторских (авторских, свежих, оригинальных, индивидуализированных) метафор пред- ставляет собой существенную особенность опыта клиента. Удачные психотерапевтические метафоры «схватывают» опыт клиента в полноте и целостности его индивидуальных особенностей, осознание и понимание которых в логике означения требуют несопоставимо больше времени и усилий (Калина, 1997).

Иначе говоря, мы имеем дело с творческим процессом смыслопорождения в рамках психотерапии как собственно метафорической коммуникации. Семиотическая сущность данного процесса описана Ю.М. Лотманом. Появление новой, принципиально новаторской метафоры оценивается носителями традиционного смысла как нечто незаконное и даже оскорбляющее их чувства и разум. Эта шокирующая метафора - всегда результат творческого акта, что не мешает ей в дальнейшем превратиться в общераспространенную и даже тривиальную. Этот постоянно действующий процесс «старения» различных способов смыслопорождения компенсируется, с одной стороны, введением в оборот новых, прежде запрещенных, а с другой - омоложением старых, уже забытых смыслопорождающих структур (Лотман, 1992).

Благодаря своей психологической структуре метафора является «мостом» между сознанием и бессознательным. Она оказывается своего рода «тележкой», перевозящей внутренние содержания клиента из сферы бессознательного в его сознание. Вместе с тем метафора представляет собой также «психологическую ловушку» для образов бессознательного, причем такую ловушку, которая позволяет расшифровывать 
(декодировать) их значение, осознавать и понимать бессознательное. Тем самым метафора (и процесс метафоризации) дает возможность интеграции в сознание клиента тех содержаний его опыта, доступ к которым закрыт для знакового означения.

\section{Символические образы в психотерапии}

Через метафоризацию и символизацию в психотерапии происходит преобразование и развитие смысловой структуры субъекта, что, собственно, и является целью многих форм психотерапии.

Метафоризация способствует прояснению опыта клиента, лучшему пониманию им самого себя: своих потребностей, установок, чувств, а также установлению, налаживанию внутренней коммуникации, интрапсихического диалога со своими внутренними содержаниями. При этом появление символического образа (в отличие от метафорического) знаменует собой еще более коренные преобразования, изменение самого «гештальта» смысловой сферы личности. Например, может произойти переоценка существующих ценностей, изменение иерархии мотивов, потеря смысла, бывшего до сих пор очевидным, или нахождение смысла там, где его не было.

Поскольку и метафора и символ являются образами, то зачастую представляется затруднительным провести между ними четкую демаркационную линию. Так, один и тот же образ, например образ костра, горящего между двумя влюбленными в ночи и согревающего их (пример из практики), можно рассматривать и как метафору, и как символ. Метафорический образ означает установление контакта, налаживание коммуникации: образ костра выступает как метафора потепления или «разогревания» уже существующих отношений между партнерами, о которых они говорили ранее как о «замороженных». Данный образ-метафора мог бы служить сознательному пониманию партнерами своих желаний, возможно, бессознательно выстраивавшихся планов на будущее. При этом не происходит «выхода» за пределы существующей, заявленной в вербальном представлении проблемы (темы).

Однако тот же образ костра может выступать в роли символа. В этом случае его содержание, трактовка его значений, возможно, будут мало чем отличаться от предыдущего случая, однако для нас принципиален контекст рассмотрения проблемы: ее вербальное представление, проговаривание. Зачастую природу образа можно определить лишь спустя определенное время, после детального обсуждения, работы с ним.

Представим себе типичный случай, когда клиентка пришла с неопределенным запросом, с жалобами телесного характера (на головные боли или физическую слабость) или с жалобами на неуверенность в себе. Терапевт пытается помочь ей разобраться в том, что за этим стоит, с помощью средств арт-терапии. В этом случае описанный ранее образ можно считать символом, поскольку он позволяет не просто уточнить смысл опыта, а обрести этот смысл (например, плохое физическое самочувствие, головные боли или проблемы на 
работе обусловлены неудовлетворенной потребностью в теплых межличностных контактах). В этом случае более нагляден неожиданный переход к, казалось бы, посторонней теме, не связанной с заявленной изначально.

Таким образом, метафорический образ ближе сознанию клиента, его легче понять и принять в качестве дополнения и расширения наличного опыта, здесь не существует «пропасти» между знаемым, вербально опосредованным опытом и опытом, образно опосредованным, меньше субъективное расстояние между этими двумя видами опыта. Метафорический образ понимается быстрее. Символический образ может быть неожиданным, странным, загадочным, казалось бы, не связанным со знаемым опытом и даже никак к нему, на первый взгляд, не относящимся. Символический образ зачастую оказывается сложнее понять и принять, включить в контекст наличных представлений, однако при этом он воспринимается не как чуждый, а как восполняющий «уникальность нехватки». Символический образ имеет сложный, противоречивый характер: он может переживаться одновременно и как свой, и как чужой, и как близкий нашему Я, и как бесконечно далекий.

Поскольку метафорические образы способствуют расширению и углублению понимания опыта, прояснению знаемых смыслов, тогда как символические образы - преобразованию, смене смысловой перспективы, новому взгляду на существующую проблему или «высвобождению» иной, более актуальной и значимой проблематики, то может возникать искушение рассматривать символический образ как метафорический, сведя его к знакомому «это всего лишь»: например, к метафорическому выражению сексуального влечения.

В свое время К.Г. Юнг предлагал подразделять образы на симптоматические (метафорические в нашей терминологии) и символические (Юнг, 1994). Понимаемый терапевтом иносказательный смысл симптома (физических дискомфортов, истерических недомоганий, отыгрываний и т. п.) позволяет увидеть его скрытую от сознания клиента коннотативную смысловую структуру, но смысловая структура символического образа является гораздо более сложной. В качестве символических образов К.Г. Юнг называет, например, образы мандалы (как соединяющей круговые и квадратичные структуры). При этом круг метафорически для него изображает бессознательное, а квадрат - сознание, но уже их соединение - это не метафора, иносказание какого-то общего для всех смысла, но символ - это каждый раз уникальное соединение сознательных и бессознательных содержаний в неожиданное, новое единство. Поэтому он называл такие символы «яслями», поскольку в них рождаются новые смысловые структуры, а не проясняются и осознаются уже имеющиеся.

К.Г. Юнг делает особый упор именно на динамичности отношений сторон символа. Среди разнообразных отношений сознания и бессознательного К.Г. Юнг выделяет принципиально для него важное - процесс индивидуации, происходящий при интеграции содержаний сознания с 
содержаниями бессознательного. Индивидуация осуществляется благодаря трансцендентальной функции, объединяющей противоположности. Ее цель в том, чтобы сознание, избежав поглощения архетипами (содержаниями бессознательного), воспользовалось их энергией для восхождения к центру homo totus'a (целостной личности) - Самости.

Рассмотрим пример, содержащий два образа клиентки, один из которых имеет, согласно нашему мнению, метафорическую, а другой символическую природу. В вербальном представлении запроса доминирует тема сложности выстраивания межличностных отношений с друзьями и близкими. Метафорический образ представляет проблему несколько глубже: клиентка ощущает себя как бы заколдованной, т. е. плохое обращение с близкими вызвано некоей силой извне, ей не подвластной. Здесь мы сталкиваемся с нежеланием клиентки нести ответственность за свои действия, стремлением переложить эту ответственность на обстоятельства. Но если данный образ лишь раскрывает проблему, позволяя углубить понимание ее психологических механизмов, то следующий образ почти парадоксален, будто бы вырван из контекста. Это рисунок «атипичной кардиограммы». Здесь мы сталкиваемся уже с переживаниями клиенткой своей проблемы на телесном, физиологическом уровне, ощущением своей «атипичности», проявляющейся не узко, локально, а глобально. Проблема здесь не просто становится понятнее, а расширяется по охвату, затрагиваются новые, неисследованные области субъективности.
Наглядное представление о метафорическом и символическом означениях дает, на наш взгляд, «случай Джен» из практики К. Роджерса (Роджерс, 2001). После установления безопасного контакта пациентка может обратиться к своим содержаниям и позволяет проявиться чувствам. Она «исследует свой опыт», т. е. непосредственно взаимодействует с ним, пытается означить, выразить его в словах, причем как можно точнее, чтобы словесная формулировка входила в резонанс с самими содержаниями. Это дает ей возможность продолжать работать со своим опытом, чувствуя «реальность, твердость, незыбкость почвы под ногами», т. е. ей есть от чего оттолкнуться, чтобы продолжить дальнейшее движение. Означивание можно представить как восхождение по ступенькам, каждой из которых является экстериоризация содержания, при этом оно как будто обретает плотность, вес, реальность, подтверждаясь терапевтом. Только после того, как очередное экстериоризированное содержание обрело плотность, зафиксировалось, клиент переходит к следующему. Клиент словно избавляется от содержаний, «выбрасывает» их вовне, разотождествляясь с ними, дистанцируясь от них. При этом сами выраженные содержания получают право на самостоятельное существование, а клиент - свободу двигаться дальше. Чем дальше продвигается сеанс, тем больший накал чувств сопровождает высказываемый текст, меньше предметного значения и больше эмоциональности и образности.

Первоначально К. Роджерс способствует тому, чтобы клиентка услышала 
саму себя, точнее, те закрепившиеся паттерны понимания себя, которые наличествуют и доминируют в ее сознании. Таким образом клиентка выговаривает привычные для нее способы означения себя. Однако затем в речи клиентки начинают появляться образные выражения, что, на наш взгляд, отражает естественное развитие психотерапевтического процесса (например, Джен говорит, что хочет «убежать от старения», что чувствует себя «пойманной собственным возрастом»). Далее общение идет уже в основном на метафорическом, нежели на предметном, языке значений; у клиентки и терапевта появляется свой язык, код которого известен только им двоим, например, Джен говорит: «Все, как смерч, крутится вокруг», на что К. Роджерс откликается: «Я бы хотел помочь вам найти точку опоры во всех этих вещах, которые крутятся в вашей голове» (Роджерс, 2001).

Когда появляется образ, оформленный в виде метафоры, психотерапевтический процесс выходит на другой уровень: основная проблема определена, клиентка услышала саму себя, что позволило ей приблизиться к образному, чувственному, более глубокому плану своего внутреннего мира, своей субъектности. Начинается поиск ресурсов для разрешения этой проблемы. В случае Джен этим ресурсом оказалась «маленькая непослушная девочка», жившая до недавнего времени «внутри нее». Этот образ презентирует определенное состояние клиентки, ее часть, контакт с которой оказался утерян. Однако эта потерянная часть периодически «подает голос», «говорит» в многоголосии дискурса Джен (например, когда клиентка отмечает, что и сейчас могла бы надеть шорты и заплести косички).

Таким образом, терапевт, будучи внимателен к тексту клиентки, находит осколки этого состояния и по осколкам пытается восстановить, как выглядел «целостный сосуд». Он называет возможное ресурсное состояние в виде образа маленькой непослушной девочки, и этот образ отзывается в клиентке. В ответ в клиентке действительно актуализируется соответствующее состояние, часть ее самой, которая омертвела. Отметим важность того, что этот образ клиентка приняла, так как он символизировал для нее важную часть опыта, часть ее самой, т. е. был очень личным, хотя и актуально неосознававшимся. Данный образ запустил в ней процесс самоисследования, послужил для нее руководством к действию, начал ее направлять и вести (как и полагается символу) во внутреннем путешествии к себе самой.

С появлением этого образа в опыте Джен восполняется «уникальность нехватки». Понимание двух связанных между собой проблем (старение и боязнь вступать в брак) становится не просто более отчетливым (этот этап уже пройден), а переходит на иной уровень. Джен начинает осознавать, что страшны не сами эти события, не брак как социальный институт, не старение как естественный процесс, а те изменения в ней самой, которые влекут за собой потерю контакта со своей сокровенной частью. Таким образом, образ-символ, появляясь в психотерапевтическом общении, приводит к трансценденции ее наличного состояния, 
трансмутирует ее смыслы и ценности, ее личность в целом.

Символический образ, даже будучи выражен в ясных другим людям понятиях или чувственных формах (что, естественно, бывает не всегда, см., например, юнгианскую интерпретацию духовидческого или религиозного опыта), восполняет именно «уникальную нехватку» в жизни клиента. Он не только метафорически указывает на какие-то качества клиента, он на самом деле устраняет образовавшуюся «нехватку», «встраивая» недостающую часть личности клиента в целостность его психической жизни.

\section{Заключение}

Предпринятое в статье рассмотрение трех качественно специфичных способов опосредования расширяет и уточняет, на наш взгляд, общепсихологическую концепцию знакового опосредования, разработанную в свое время Л.С. Выготским (Выготский, 1983). В данной связи известный «треугольник Выготского» может быть представлен следующим образом (рисунок 1).

Исходя из представленных выше трех способов опосредования (означение - метафоризация - символизация), мы предполагаем, что ответственная за них субъектность также структурирована триадически. Рассмотрение этой интрапсихической триады нами было подробно осуществлено в рамках триалогического подхода к психотерапии-консультированию (Орлов, 1998, 2002).

Ключевой, основополагающей категорией этого подхода является категория триалога - троегласия и троебытия человека.

Триалог - это реальный феномен практики психотерапии-консультирования, которая лишь на первый взгляд являясь диалогическим общением тет-а-тет, всегда включает в себя не только две позиции, два голоса психотерапевта-консультанта и пациента-клиента, но также позицию (голос) наблюдателя - третьего участника общения. При этом позиция

Рисунок 1

Три средства (способа) опосредования: знак (означение), метафора (метафоризация), символ (символизация)

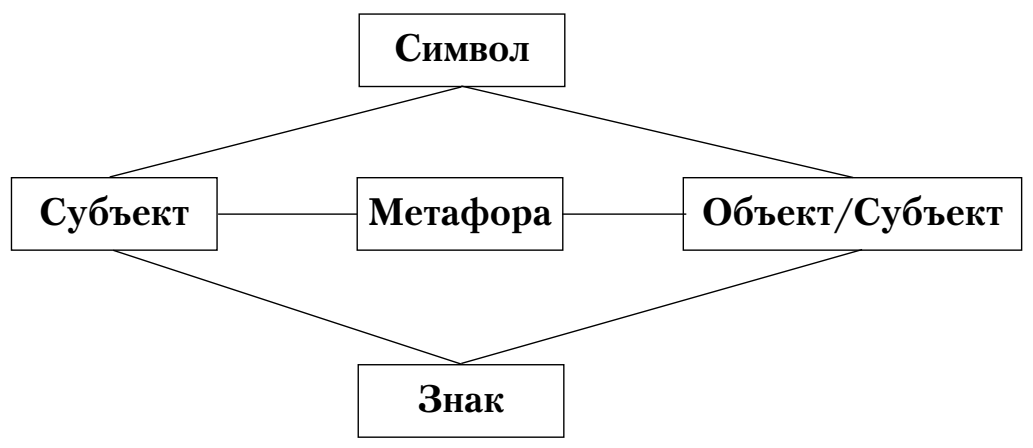


наблюдателя в практике психотерапевтического консультативного общения представлена двояко, в двух различных, диаметрально противоположных ипостасях (плоскостях). С одной стороны, это позиция наблюдателя-супервизора, того значимого Другого, который обеспечивает профессиональное и личностное становление психотерапевта-консультанта, инициирует его приобщение к практике психотерапии-консультирования, осуществляет передачу профессионального мастерства и ремесла. С другой - это позиция наблюдателясубвизора (наблюдателя со стороны пациента-клиента), того значимого Другого, участие которого в жизни пациента-клиента в значительной степени определяет его проблему и запрос. Позиции психотерапевта-консультанта, наблюдателя-супервизора и пациента-клиента образуют внешнюю триаду (триалог) психотерапевта-консультанта. Позиции психотерапевта-консультанта, наблюдателя-субвизора и пациента-клиента образуют внешнюю триаду (триалог) пациента-клиента. Таким образом, полная позиционная интерперсональная структура практики психотерапии-консультирования включает в себя два совмещенных внешних триалога, две внешние триады.

Содержание триалогического подхода к психотерапии-консультированию задается не только рассмотренными выше основными значениями категории «триалог», но и тремя основными идеями данного подхода.

1. Идея трех территорий. Переход от классической (умозрительной) к постклассической (экспериментальной и практической) психологии, связанный с именами
В. Вундта, А. Бине и 3. Фрейда, существенным образом изменил научные представления о субъекте (личности) как некоем самовластном центpe психической жизни человека. Благодаря работам в области экспериментальной и практической психологии личность человека перестала рассматриваться в качестве целостного субъекта, превратилась в расщепленную, внутренне противоречивую, сложную и динамическую конструкцию. На смену кредо Р. Декарта «Я мыслю, следовательно, я существую» пришло замечательное по своей точности и проницательности кредо Ж. Лакана «Я мыслю не там, где я существую» (цит. по: Романов, 1994, с. 253). Используя систему представлений триалогического подхода, эту переформулировку Ж. Лакана можно, в свою очередь, преобразовать, представив ее в следующем виде: «Я изживаю не там, где я переживаю, и я переживаю не там, где я живу». Таким образом, любого человека (в том числе любого психотерапевта-консультанта и любого пациента-клиента) можно рассматривать как одновременно существующего и проявляющегося в трех различных планах или на трех различных территориях: изживания-действия, переживаниячувства и проживания-бытия.

2. Идея трех внутренних инстанций. Я (Эго) человека, осваивая каждую из трех территорий, выступает каждый раз в качестве особого «субъекта». На территории изживания-действия Я человека выступает как «социальный» аспект личности или как внутренний наблюдатель, на территории переживания-чувства как «субъективный» аспект личности 
или как внутренний клиент, а на территории проживания-бытия как «субъектный» аспект личности или как внутренний терапевт.

3. Идея трех языков. Проявления Я (Эго) человека на трех территориях в качестве трех указанных «субъектов» или аспектов личности человека можно охарактеризовать как различные формы говорения, различные голоса или языки: внутренний наблюдатель использует знаковый язык поведения и мышления, внутренний клиент - метафорический язык тела и внутренних образов, внутренний терапевт - символический язык трансцендирующих (в терминологии К.Г. Юнга) состояний.

\section{Литература}

Баркер Ф. Использование метафор в психотерапии. Воронеж: НПО «МОДЭК», 1995.

Барm P. S/Z. M.: Ad Marginem, 1994

Бибихин В.В. Язык философии. М.: Наука, 2007.

Булгаков С.Н. Философия имени. Париж: YMCA-Press, 1953.

Васильев B.B. Трудная проблема сознания. М.: Прогресс-Традиция, 2009.

Выготский Л.С. Собр. соч.: В 6 т. М.: Педагогика, 1982, Т. 2; 1983, Т. 6.

Гадамер $X .-Г$. Истина и метод: Основы философской герменевтики. М.: Прогресс, 1988.

Гегель Г.В.Ф. Соч. М.: Гос. социальноэкономическое изд-во, 1938. Т. 12. Кн. 1.

Ильенков Э.В. Диалектика идеального // Логос. 2009. № 1. С. 6-62.
В силу этого для пациента-клиента психотерапевтический консультационный процесс развивается как последовательность, складывающаяся из трех основных этапов: 1) принятие психотерапевтом-консультантом когниций (мыслей и представлений) клиента (эмлогия); 2) сочувственное понимание эмоций (переживаний и чувств) клиента (эмпатия); 3) конгруэнтное выражение интуиций и образов клиента (эмфилия). Психотерапия в целом рассматривается нами как такая поступательная и «восходящая» актуализация уровней субъектности клиента посредством знакового, метафорического и символического языков.

Калина Н.Ф. Основы психотерапии: Семиотика в психотерапии. М.: Рефлбук; К.: Ваклер, 1997.

Кассирер Э. Избранное: Опыт о человеке. М.: Гардарика, 1998.

Кроль Л. Образы и метафоры в интегративной гипнотерапии. М.: Класс, 1999.

Леоненко Е.А., Тимошенко Г.В. Метафора и телесная метафора в психотерапии: опыт осмысления систематизации // Психология телесности: Между душой и телом / Под ред. В.П. Зинченко, Т.С. Леви. М.: АСТ, 2005. С. 614-641.

Лосев А.Ф. Проблема символа и реалистическое искусство. М.: Наука, 1978.

Лотман Ю.М. Культура и взрыв. М.: Прогресс, 1992.

Мамардашвили М.К. Лекции о Прусте. M.: Ad Marginem, 1995. 
Момджян К.X. Введение в социальную философию. М.: Высш. шк.; КД «ниверситет», 1997.

Орлов А.Б. Человекоцентрированное консультирование как область практики и учебная дисциплина: триалогический подход // Развивающаяся психология основа гуманизации образования / Под ред. В.Я. Ляудис, Н.Н. Корж. М.: РПО, 1998. С. 172-173.

Орлов А.Б. Психологическое консультирование и психотерапия: триалогический подход // Вопросы психологии. 2002. № 3. С. 3-19.

Роджерс К. Клиентоцентрированный/человекоцентрированный подход в психотерапии // Вопросы психологии. 2001. № 2. С. 48-58.

Романов И.Ю. Психоанализ: культурная практика и терапевтический смысл: Введение в теорию, практику и историю психоанализа. М.: Интерпракс, 1994.

Серкин В.П. Методы психологии субъективной семантики и психосемантики: Учебное пособие для студентов высших учебных заведений, обучающихся по направлению и специальностям психологии. М.: ПЧЕЛА, 2008

Скейфи С. Диалектика арт-терапии // Арт-терапия / Сост. А.И. Копытин. СПб.: Питер, 2001.

Теория метафоры. М.: Прогресс, 1990. Шеллинг Ф.В. Философия искусства. М.: Мысль, 1966.

Юнг К.Г. Либидо, его метаморфозы и символы. СПб.: Восточно-Европейский институт психоанализа, 1994.

Юнг К.Г. Mysterium coniunctionis. М.: Рефл-бук; К.: Ваклер, 1997.

Якобсон Р. В поисках сущности языка // Семиотика. М.: Радуга, 1983.

Cassirer E. Symbol, myth and culture: Essays and lectures. New Haven; London: Yale University Press, 1979.

Edwards D. Art Therapy. Creative Therapies in Practice. London: SAGE, 2004.

Platonis. Opera. Oxonii, 1905-1913. T. 2.

Weinberg $B$. The limits of symbolism. Chicago; London: The University of Chicago Press, 1966. 